\title{
Accumulation of Iron-59 in Marine Animals from Different Uptake Route
}

\author{
Yutaka TATEDA, ${ }^{* 1}$ Motokazu NAKAHARA, ${ }^{* 2}$ and Taku KoYANAGI*2 \\ (Accepted April 20, 1983)
}

\begin{abstract}
The accumulation of ${ }^{59} \mathrm{Fe}$ by abalone Haliotis discus and right-eye flounder Kareius bicoloratus from different uptake mode was investigated. Whole body of ${ }^{58} \mathrm{Fe}$ of abalone taken up from sea water showed concentration factor of $66 \pm 19$ at 6 day accumulation. Elimination patterns of ${ }^{50} \mathrm{Fe}$ from abalone taken up from sea water and by oral administration were different from each other and with regard to that of right-eye flounder. Distribution ratio of ${ }^{50} \mathrm{Fe}$ in abalone taken up from sea water was high in the liver, contrary to the results of oral administration showing the high being in the muscle. Right-eye flounder in oral administration showed high distribution of ${ }^{80} \mathrm{Fe}$ in the liver against the report of sea water uptake showed in the intestine. The combining form of ${ }^{80} \mathrm{Fe}$ in constituent organs was observed at same elution volume in spite of the difference of uptake mode and species.
\end{abstract}

In marine ecosystem, many factors affect the behavior of radionuclides and it is known that biological concentration or tissue distribution of radionuclides in marine organisms are influenced by the mode of uptake as well as other various environmental and biological factors. Accumulation of radionuclides by marine organisms via food or via water has been examined on some combinations of nuclide-organism and the concentration of each route of uptake is estimated specifically dependent of the nuclide. ${ }^{1-8}$ ) The conculusive assignment is, however, not always derived due to the differences of physico-chemical forms of the nuclides or the diversities of preypredator relationships, but also the information is scarce on the accumulation of radioactive iron through the different routes by marine organisms. The present study is concerend with retention and tissue distribution of radioactive iron in abalone Haliotis discus polluted in laboratory via food or via water, and the results were compared with the results of right-eye flounder Kareius bicoloratus.

\section{Materials and Methods}

The abalone Haliotis discus (average weight $12.9 \mathrm{~g}$ ), hatched in Fisheries Experimental Station of Ibaraki Prefecture and right-eye flounder Kareius bicoloratus (average weight $191.8 \mathrm{~g}$ ), caught in the Pacific coast of Ibaraki Prefecture were used in the experiment after acclimation in the aquarium with $200 l$ of seawater.

Ten abalones were reared in $3 l$ of seawater containing $200 \mu \mathrm{Ci}$ of ${ }^{8 \theta} \mathrm{Fe}(13.1 \mathrm{mCi} / \mathrm{mg} \mathrm{Fe}$ as ferrous sulfate) for 1 week to observe the accumulation. Then the half of individuals were transfered into non-radioactive seawater and excretion of the radionuclide was observed for 3 weeks at $16^{\circ} \mathrm{C}$. The radioactivity of abalone was measured periodically during the uptake and loss experiments with a scintillation counter (Armac Scintillation Detector, model 446 with Tri-curb Scintillation Spectrometer, model 3001 Packard).

Five abalones and four right-eye flounders were administered $20 \mu \mathrm{Ci}$ and $25 \mu \mathrm{Ci}$ of ${ }^{89} \mathrm{Fe}$ with $\alpha$ starch or gelatine, respectively, and retention of radioactivities was followed for 3 weeks measuring the whole body radioactivities of animals reared in non-radioactive seawater at $16^{\circ} \mathrm{C}$. After the excretion experiments the distribution of residual radioactivities in the animals was compared between the sacrificed individuals polluted via food and via water, respectively.

On some organs of the animals the gel filtration chromatography (GEC) with Sepharose 4B (Pharmacia Fine Chemicals, Sweden) was applied to examine the combining of ${ }^{58} \mathrm{Fe}$ in the organs and also examine the effect of difference in the uptake

*1 Bio-Evironmental Laboratory, Central Institute of Electric Power Industry, 1646, Abiko, Chiba 270-11, Japan（立田 饗：電力中研生物環境技術研究所).

*2 Division of Marine Radioecology, National Institute of Radioecological Science, 3609 Isozaki, Nakaminato, Ibaraki 311-12, Japan（中原元和・小楖 卓：放射線医学総合研究所）. 
mode. Sepharose 4B was soaked in the tris- $\mathrm{HCl}$ buffer solution of $\mathrm{pH} 8.32$ at room temperature and then packed into the column of $2.6 \mathrm{~cm} \mathrm{I}$. D. and $65 \mathrm{~cm}$ height. The each organ of the animals was homogenized in the buffer solution and centrifuged at $10,000 \mathrm{rpm}$ for 40 minutes at $5^{\circ} \mathrm{C}$. The supernatant was added on the column and eluted with the buffer solution in a flow rate of $0.4 \mathrm{ml} /$ min. maintained by peristalic pump. The aliquots fraction were collected continuously for subsequent radioactivity measurement with a scintillation counter (Aloka JDC-752) and the contents of proteinous matter in the effluent were measured by a UV absorption spectrometer (Hitachi 124 DB) by absorbance at $280 \mathrm{~nm}$.

\section{Results and Discussions}

\section{Accumulation of ${ }^{58} \mathrm{Fe}$ from Seawater}

The distribution of radioactivity in abalone and seawater in the aquarium was shown in Fig. 1. Radioactive iron in the seawater was lost rapidly within the initial stage and reached almost steady level during the couple of days, whereas radioactivity of the abalone increased and reached steady state after a day showing the apparent concentration factor of $66 \pm 19$. In mollusks, many studies have been reported on Mytilus edulis, ${ }^{4-\theta)}$ and Littorina obtusata, ${ }^{10)}$ though scarce on abalone. The concentration factor of ${ }^{89} \mathrm{Fe}$ in Mytilus is the order of $10^{2}$, and Littorina, $10^{8}$. The results of abalone were comparable to the value of them, though the period of observation was not always enough.

\section{Retention of ${ }^{8 \theta} \mathrm{Fe}$ Taken up from Different Routes}

Retention pattern of ${ }^{80} \mathrm{Fe}$ in the whole body of the animals was compared between the different route of uptake or the different species of animals and shown in Fig. 2. The radioactivities in whole body were eliminated almost similarly in any case of the results showing at least two components with different slopes of the loss curves. The retention curves were analyzed with the approximation of linear-function model and the biological half-lives and the loss coefficient calculated by means of the least squares method were shown in Table 1. The elimination of ${ }^{58} \mathrm{Fe}$ from the abalone reared in labelled seawater was slower than those administered orally as seen in the short component of loss curves but the difference was insignificant in the long component indicating almost unperceivable elimination. The loss of orally admini-

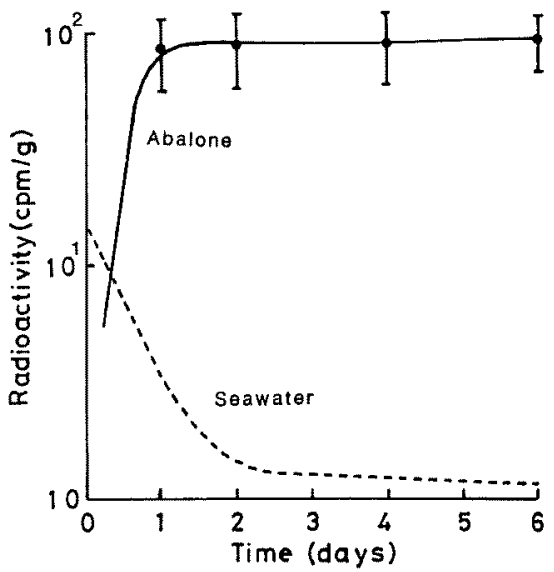

Fig. 1. Accumulation of ${ }^{5} \mathrm{Fe}($ Sulfate) from sea water by Abalone, Hariotis discus.

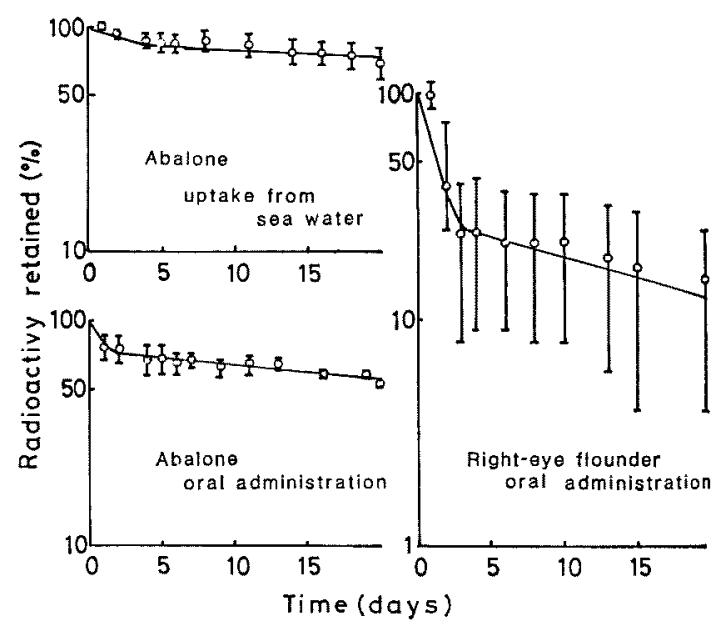

Fig. 2. Whole body retention of ${ }^{5 \theta} \mathrm{Fe}$ in Abalone Hariotis discus and Right-eye flounder Kareius bicoloratus. Each value represents the mean and standard deviation for five and four individuals, respectively.

stered ${ }^{58} \mathrm{Fe}$ was more rapid in right-eye flounder than abalone in the both short and long components. Baptist reported the similar results observed on Atlantic croaker ${ }^{11}$ ) but the biological half-lives obtained in the long component are different between two species of the fishes. The loss of ${ }^{59} \mathrm{Fe}$ from whole body of the fish has been also observed by PeNTreath ${ }^{12)}$ on plaice but the comparison of biological half-lives among these fishes is difficult because of the difference in experimental methods. KoYANAGI ${ }^{13)}$ reported the retention pattern of ${ }^{8 \theta} \mathrm{Fe}$ in right-eye flounder and the results were quite comparable in spite of different administrating procedures. 
Table 1. Parameters for retention patterns of ${ }^{58} \mathrm{Fe}$ taken up from different route by Abalone Hariotis discus and Right-eye flounder Kareius bicolratus

\begin{tabular}{|c|c|c|c|c|}
\hline \multirow{2}{*}{ mode of uptake } & \multicolumn{3}{|c|}{ Abalone } & \multirow{2}{*}{$\begin{array}{c}\text { Right-eye flounder } \\
\text { oral } \\
\text { administration }\end{array}$} \\
\hline & $\begin{array}{l}\text { taken up from } \\
\text { sea water }\end{array}$ & \multicolumn{2}{|c|}{$\begin{array}{l}\text { oral } \\
\text { administration }\end{array}$} & \\
\hline \multicolumn{5}{|c|}{ Short component } \\
\hline$T_{b 1}$ (days) & 33.1 & 2.7 & \multicolumn{2}{|r|}{1.5} \\
\hline$b_{1} \quad\left(\right.$ days $\left.^{-1}\right)$ & 0.0363 & \multicolumn{2}{|l|}{0.2744} & 0.4708 \\
\hline$f_{1}$ & 1.02 & \multicolumn{2}{|c|}{1.00} & 1.16 \\
\hline \multicolumn{5}{|c|}{ Long component } \\
\hline$T_{b 2}$ (days) & - & 548 & \multicolumn{2}{|r|}{28.6} \\
\hline$b_{2} \quad$ (days $\left.^{-1}\right)$ & 0.0136 & 0.0162 & \multicolumn{2}{|r|}{$0.036 ́ 1$} \\
\hline$f_{2}$ & 0.93 & 0.76 & \multicolumn{2}{|r|}{0.28} \\
\hline \multicolumn{5}{|c|}{$\begin{array}{l}Q_{t}=Q_{0}\left(f_{1} e^{-b_{1} t}+f_{2} e^{\left.-b_{2} t\right)}\right. \\
\text { where } \\
Q_{t}: \text { the whole body radioactivity at the time } t \text { after the initial of excretion. } \\
Q_{0}: \text { the whole body radioactivity at the initial of excretion. } \\
f_{1,2}: \text { the fractions of radioactivity lost with the coefficient } b_{1} \text { and } b_{2}, \text { respectively. } \\
b_{1,2}: \text { loss coefficients of the fractions } f_{1} \text { and } f_{2} \cdot\left(b_{1,2}=0.693 / T_{\epsilon 1,2}\right) \\
T_{e 1,2}: \text { effective half-lives of the fractions } f_{1} \text { and } f_{2} . \\
T_{b 1,2}: \text { biological half-lives of the fractions } f_{1} \text { and } f_{2} \text {. }\end{array}$} \\
\hline \multirow{2}{*}{ Organs or tissues } & \multirow{2}{*}{ Weight per cent } & \multicolumn{2}{|c|}{$\begin{array}{l}\text { taken up from } \\
\text { sea water }\end{array}$} & \multirow{2}{*}{$\frac{\begin{array}{c}\text { oral } \\
\text { administration }\end{array}}{3 \text { week excretion }}$} \\
\hline & & 1 week uptake & 3 week excretion & \\
\hline Shell & $35.2 \pm 1.5^{*}$ & $21.2 \pm 6.1$ & $5.5 \pm 1.7$ & $5.2 \pm 0.9$ \\
\hline Muscle & $40.4 \pm 1.9$ & $10.8 \pm 1.5$ & $10.6 \pm 1.5$ & $52.6 \pm 6.2$ \\
\hline Liver & $13.6 \pm 2.4$ & $55.0 \pm 9.0$ & $73.5 \pm 6.0$ & $21.7 \pm 7.2$ \\
\hline Gill & $1.0 \pm 0.4$ & $2.4 \pm 0.9$ & $3.2 \pm 0.6$ & $3.7 \pm 0.5$ \\
\hline Viscera & $8.9 \pm 2.4$ & $5.1 \pm 2.6$ & $6.5 \pm 2.9$ & $18.0 \pm 2.9$ \\
\hline Gonad & $1.4 \pm 2.1$ & $2.7 \pm 2.1$ & $1.7 \pm 0.5$ & $0.8 \pm 0.3$ \\
\hline
\end{tabular}

* Each value represents the mean and $s$ andard deviation for five indviduals.

\section{Distribution of ${ }^{59} \mathrm{Fe}$ in the Animals}

The distribution of radioactivity in the abalones was compared between two routes of uptake and shown in Table 2. with the weight percent of each organ or tissue. The most of ${ }^{80} \mathrm{Fe}$ taken up from seawater was distributed in the liver and the distribution ratio of the liver continued to increase even during the loss experiment with decrease in that of the shell. In the case of oral administration, the distribution ratio was highest in muscle, followed by liver. It indicated that ${ }^{\circ \theta} \mathrm{Fe}$ taken from seawater was mainly transported to the liver and from the food went to the muscle in abalone. In mussel, Mytilus edulis, high concentration factors of organs were reported on stomach and digestive gland ${ }^{8)}$ or viscera, ${ }^{8)}$ but no data about accumulation from food.

The distribution ratio of ${ }^{80} \mathrm{Fe}$ in right-eye flounder administered orally were shown in Table
Table 3. Distribution of ${ }^{\circ} \mathrm{Fe}$ in Right-eye flounder Kareius bicoloratus from oral administration

\begin{tabular}{lrr}
\hline $\begin{array}{c}\text { Organs } \\
\text { or } \\
\text { tissues }\end{array}$ & $\begin{array}{c}\text { Weight } \\
\text { per } \\
\text { cent }\end{array}$ & $\begin{array}{c}\text { Distribution } \\
\text { ratio of } \\
\text { Ba Fe (\%) }\end{array}$ \\
\hline Muscle & $51.8 \pm 4.1^{*}$ & $2.9 \pm 2.0$ \\
Liver & $1.3 \pm 0.4$ & $22.6 \pm 7.7$ \\
Gill & $1.7 \pm 0.2$ & $1.5 \pm 0.4$ \\
Viscera & $3.1 \pm 1.9$ & $43.5 \pm 9.5$ \\
Blood & $2.9 \pm 0.6$ & $2.6 \pm 2.6$ \\
Bone & $14.0 \pm 1.1$ & $1.3 \pm 1.3$ \\
Skin & $6.4 \pm 1.3$ & $1.2 \pm 1.3$ \\
Head & $17.5 \pm 1.4$ & $5.7 \pm 1.6$ \\
Kidney & $0.5 \pm 0.2$ & $4.7 \pm 2.4$ \\
Spleen & $0.1 \pm 0.0$ & $0.9 \pm 0.4$ \\
\hline * Each value represents the mean and standard deviation for \\
four individuals.
\end{tabular}

3. with the percentage of the weight of each organs. The liver and viscera showed high distribution 


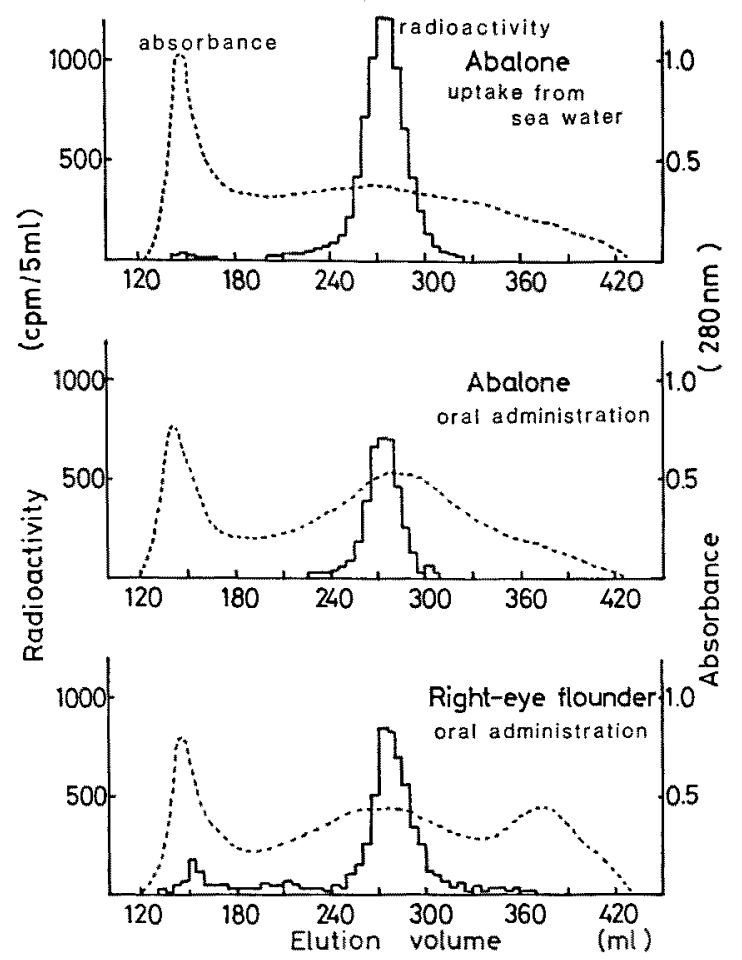

Fig. 3. GFC elution profile of ${ }^{80} \mathrm{Fe}$ and proteinous matter in the liver of Abalone Hariotis discus and Right-eye flounder Kareius bicoloratus.

ratios. The results were different from that of abalone, though the same administered method was applied, and also different from the value about plaice. ${ }^{123}$ KOYANAGI ${ }^{15)}$ reported the concentration factor of organs of right-eye flounder taken up from labelled seawater and indicated that intestine was most accumulative. The results of this experiment showed the route of uptake by food affect the distribution ratio, because of the liver was most accumulative in the result.

The Binding of ${ }^{50} \mathrm{Fe}$ to the Constituents of Body Tissues

The results of GFC on the extracts of the liver of abalone and right-eye flounder are shown in Fig. 3. Most of the radioactivity of ${ }^{80} \mathrm{Fe}$ in the liver was eluted in the region of fractions in $250 \mathrm{ml}$. The results showed that both in the liver of abalone and right-eye flounder, one kind of proteinous matter was the main binder of ${ }^{89} \mathrm{Fe}$. The results of GFC on the extracts of the intestine are shown in Fig. 4. All of them showed two peaks of radioactivity and higher one seems to be same as that of liver. The results of the muscle are shown in Fig. 5. They were similar to that of the intestine,

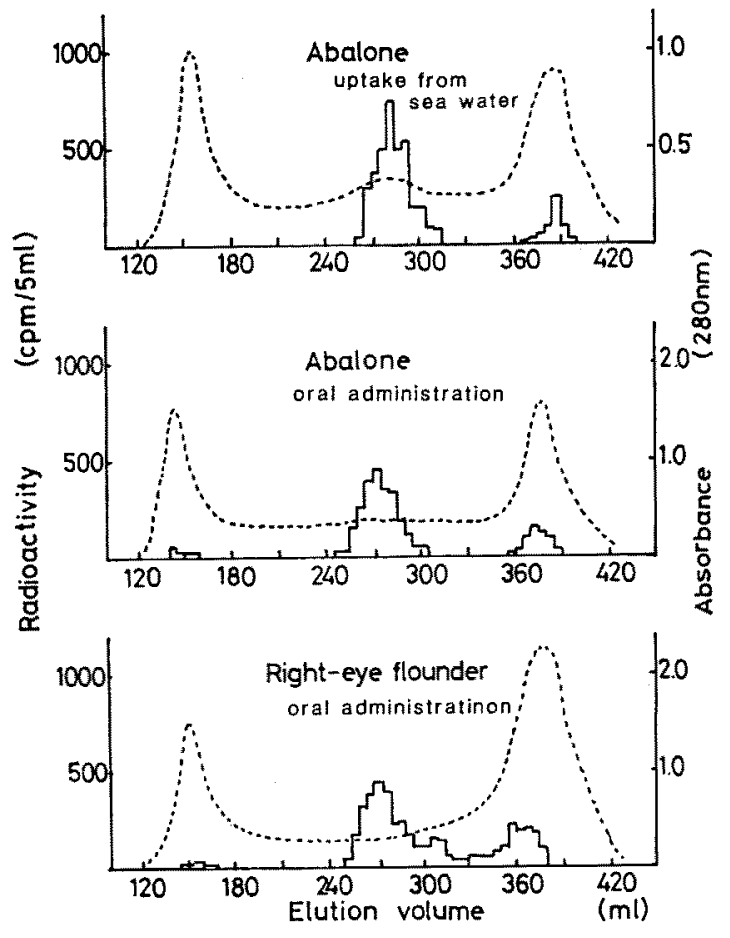

Fig. 4. GFC elution profile of ${ }^{8} \mathrm{Fe}$ and proteinous matter in the intestine of Abalone and Righteye flounder.

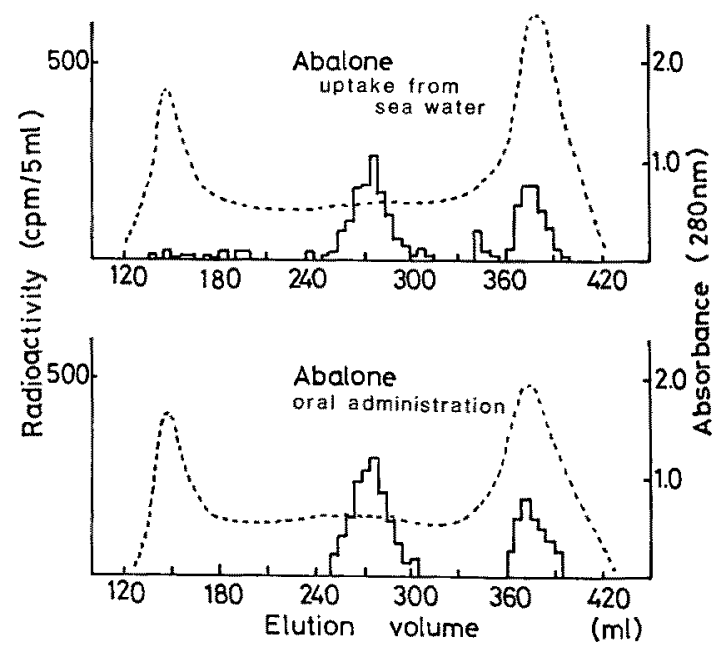

Fig. 5. GFC elution profile of ${ }^{80} \mathrm{Fe}$ and proteinous matter in the muscle of Abalone.

also having the same proteinous matter.

Considering the distribution ratio and the GFC profile of liver and intestine, most of ${ }^{\circ \theta} \mathrm{Fe}$ taken up was supposed to exist in the single proteinous matter in extracts, and it was estimated to be ferritin by the gel filtration profile of standard ferritin 
(M. W. 440, 000). Most of Fe in the fish is said to be existed in the blood cells, ${ }^{14-15)}$ but the assay on whole blood of the fishes was insufficient in the present study for the substantial comparison with them. Besides the existance in the blood cells, however, the binding of ${ }^{80} \mathrm{Fe}$ to the proteinous matter, such as ferritin, was suggested from the results indipendent of organs or species of the animals studied.

\section{References}

1) R. J. Pentreath: in "Radioactive Contamination of the Marine Environment", IAEA, Vienna, 1972, pp. 421-436.

2) G. W. BRYAN: Phil. Trans. R. Soc. Lond. B., 286, 483-505 (1979).

3) Y. Suzuki, M. Nakahara, R. Nakamura, and T. UEDA: Bull. Japan. Soc. Sci. Fish., 45, 14091416 (1979).

4) D. J. Hobden: I. Mar. Biol. Ass. U. K., 47, 597606 (1967).

5) D. J. Hobden: J. Mar. Biol."Ass. U. K., 49, 661668 (1969).
6) R. J. Pentreath: J. Mar. Biol. Ass. U. K., 53, 127-143 (1973).

7) A. Fraizier and J. Ancellin: in "Combined Effect of Radioactive, Chemical and Thermal Releases to the Environment", IAEA, Vienna, 1975, pp. 51-66.

8) A. Fraizier and J. ANCELliN: in "Impacts of Nuclear Releases into Aquatic Environment", IAEA, Vienna, 1975, pp. 49-62.

9) S. G. George, B. J. S. Pirie, and T. L. Coombs: J. Exp. Mar. Biol. Ecol., 23, 71-84 (1976).

10) M. L. Young: J. Mar. Biol. Ass. U. K., 55, 583-610 (1975).

11) J. P. Baptist, D. E. Hoss, and C. W. Lewis: Health Phys., 18, 141-148 (1970).

12) R. J. Pentreath: J. Exp. Mar. Biol. Ecol., 12, 315-326 (1970).

13) T. Koyanagi, M. Nakahara, and M. Immura: J. Radiat. Res., 19, 295-305 (1978).

14) G. Heresy, D. Lockner, and K. Sletten: Acta Physiol. Scand., 60, 256-266 (1964).

15) J. P. van DiJk, A. K. Lagerwerf, H. G. VAN Eujk, and B. LeIJese: J. Comp. Physiol., 99, 321-330 (1975). 